\title{
Accounting for greenfield union organising outcomes
}

\begin{abstract}
This paper presents a framework for evaluating and accounting for the outcomes of 'greenfield' union organising campaigns. It argues that previous studies have tended to focus too much on the establishment of collective bargaining and negotiation of first contract as a campaign outcome. Instead, the effectiveness and representativeness of new union structures are emphasised, and the sustainability of those structures is emphasised as the most important outcome. A key finding from the empirical data is that campaigns that build both workplace activism and are coordinated by officers create more sustainable outcomes than campaigns that focus on one or the other. The evidence show how and why these outcomes emerge and the paper concludes with a consideration of the theoretical and practical implications of this finding.
\end{abstract}

Word count: 10813 


\section{Introduction}

Given the increased attention to trade union organising in recent years and the significant investment in such activity by labour movements in many countries, it is important that we reflect on how effective unions have been in achieving organising objectives. In common with other countries (Carter et al., 2003, Fairbrother and Yates, 2003, Milkman and Voss, 2004), UK unions have invested heavily in training specialist organisers and have initiated campaigns to build membership and representation in workplaces where they have weak or moribund structures. A particular focus has been on establishing themselves in workplaces that have not previously been unionised - so called 'greenfield' organising campaigns (Heery et al., 2000b, Heery et al., 2003a). However, few studies have explicitly developed a framework through which to understand the factors that influence organising outcomes. The purpose of this paper is therefore to present a framework and to use it to explain variation in the effectiveness, representativeness and sustainability of outcomes in organising campaigns where unions have established a presence for the first time.

The paper argues that previous studies fail to capture the diversity of organising outcomes largely because they use binary measures of whether or not particular objectives (recognition, bargaining first contract, membership engagement structures etc.) have been achieved at the point where a union withdraws resources from the campaign. In particular, previous approaches have often defined greenfield organising 'success' or 'failure' in terms of whether or not bargaining rights are established (see Bronfenbrenner, 1997 for a seminal study). Factors influencing 'success' or 'failure' in these studies have primarily been identified as variations in organising campaign tactics (see Bronfenbrenner, 1997, Ferguson, 2008, Heery et al., 2000b, Lynn and Brister, 1989 for studies advocating this position approach to some degree). The limitation of this is that the meaning and outcomes of recognition and bargaining vary considerably in different settings. Equally problematically, it pays little attention to what happens after recognition has been granted. Thus, it has become essential to move beyond binary measures of organising outcomes to explore the sustainability of different campaign outcomes and the conditions under which sustainable organising outcomes can be secured.

This paper first examines different approaches to evaluating organising outcomes, before proposing a framework that allows us to capture a more qualitatively nuanced spectrum of outcomes. The central argument is that it is not sufficient to understand outcomes simply as a function of organising campaign tactics. Rather, the wider features of union structures and policies, the behaviour of employers and the wider context must be accounted for if we are to build a sophisticated understanding of why some campaigns are more likely than others to create sustainable gains for the labour movement. This paper analyses longitudinal data through a framework that focuses on the dynamics of organising campaigns. This allows for explanation of why and how particular aspects of campaigns facilitate and hinder sustainable organising outcomes in a way that previous studies have not. The research compares five organising campaigns that have all been identified by the unions involved as being 'successful'. There is, nonetheless, considerable 
variation in relation to the representativeness, effectiveness and sustainability. These variations are, it is argued, a function of the very different approaches to organising by the unions and the different contexts within which the campaigns take place. In other words, tactics employed during the campaigns are not, in and of themselves, sufficient to explain the variation in outcome. By considering the outcomes of particular approaches to and contexts of organising, the strengths and weaknesses of different approaches become visible. The central finding of the paper is that outcomes are most sustainable when there is both strong and representative workplace engagement and collective bargaining strength beyond the workplace.

\section{Evaluating organising outcomes}

Important early studies using US organising data (Bronfenbrenner, 1997; Bronfenbrenner and Juravich, 1998; Fiorito et al., 1995) used primarily quantitative methods to evaluate the impact of campaign tactics on organising outcomes. The US statutory processes for union recognition usually require data regarding the employer and the target workplaces to be lodged with the National Labor Relations Board (NLRB), thus giving researchers access to data on a range of aspects of both successful and unsuccessful campaigns. In conjunction with information on the tactics used by unions, these early studies identified a range of tactics which, when used together, significantly increased the likelihood of unions winning recognition and successfully negotiating a first contract (Bronfenbrenner, 1997, Bronfenbrenner and Juravich, 1998). Specifically, they provided rigorous evidence stressing the importance of unions building rank-and-file activism to tackle collective issues at workplace level. It is difficult to under-estimate the influence of these studies on both academic and practitioner debates in the US and beyond. Despite the importance and influence of these studies, the focus on the two key binary variables of 'success' or 'failure' (recognition and first contract) created the danger that these were seen as the most important, or only, outcomes of organising activity. More recent debates (Gall and Fiorito, 2011, Simms and Holgate, 2010) have problematised this perspective, but few studies have developed a systematic framework through which to evaluate organising outcomes more widely.

The limitations of a binary approach to evaluating organising outcomes are evident in the example of UK employment relations where the empirical basis of this paper is located. In the UK, bargaining is not necessarily limited to covering a particular workplace or organisation. Equally, recognition of the union is not limited to a formal, legalistic process, nor does it necessarily include recognition for collective bargaining over terms and conditions of work. UK labour law, for example, explicitly allows for workers to be represented by their union in an individual grievance or disciplinary case even where employers formally reject collective bargaining. In other words, the binary approach to measuring organising outcomes fails to account for the extent and effectiveness of the union in influencing managerial decision making. Conversely, the binary approach leaves little opportunity to integrate the idea that union structures may exist, but be extremely unrepresentative of the workforce either in numerical terms (level of membership density) or more qualitative aspects such as the extent and nature of membership activism and engagement. Most importantly, binary measures allow little scope to evaluate whether or not union influence in the workplace is durable 
over time. For all of these reasons, a wider and more nuanced range of outcome measures is developed in Figure 1.

\title{
Framework for evaluating greenfield organising outcomes
}

\author{
FIGURE ONE HERE
}

The previous section introduced three outcome variables which each capture aspects of important debates in organising literature: 1) representativeness of union structures, 2) effectiveness of union influence on managerial decision making, and 3) the sustainability of organising campaign outcomes. These appear as the final two columns of Figure 1. This section explains how and why those outcome variables are important in evaluating greenfield organising outcomes and the kinds of evidence that may be used to reach judgments about campaign processes and outcomes.

\section{1) Representativeness of union structures}

Three important aspects of representativeness can be identified in the literature: membership density, membership activism and engagement with the wider union. Each is briefly discussed although, as we shall see, the themes and issues raised are often intertwined.

The UK has strict laws against a closed union shop, so union density is a crucially important outcome of organising activity. The main relevant measures are at workplace, company or sectoral levels. Unlike many of the other measures, density can be evaluated quantitatively, although precise figures are often difficult to calculate. Membership density at workplace and company levels is important in demonstrating that the union speaks on behalf of members. It also helps the union exert influence over managers by demonstrating both the legitimacy of the interests represented, and also the potential for the use of coercive power to be mobilised if managers are intransigent (Simms and Charlwood, 2010). At sectoral level, density is also extremely important in exerting influence to take wages and other terms and conditions out of competition and to help renew union power across society more widely (Lerner cited in Crosby, 2005).

The view that membership activism is a central objective of organising activity is frequently highlighted in organising debates. For some authors, member engagement in wider decision making structures of the union is as essential as workplace activism (Fairbrother 1996, 2000, 2003). These perspectives tend to emphasise the importance of members taking responsibility for identifying and resolving workplace issues through mobilisation, collectivisation and activism (Kelly, 1998). Union structures, it is argued, must change and adapt both to encourage this and to become more 
responsive to a member-led movement (Carter, 2000) and engagement with the wider union is necessary for this transformatory process to happen. However, in a meta-analysis of empirical evidence, Hickey et al. (2010) establish that membership activism is rarely sufficient in and of itself to promote a transformation of union structures or indeed to secure effective organising outcomes. This lends further weight to the central point made here that it is necessary to evaluate a range of different organising outcomes. This is captured in Figure 1 by showing that it is quite possible for a union to establish effective influence over managerial decision making, but not be particularly representative, and yet still achieve successful and sustainable outcomes for members (perhaps, for example, by improving terms and conditions of work).

Already we see that debates about both membership density and activism raise questions about the extent and nature of engagement of members in the wider union. Greenfield organising activity is likely to target new groups of members and the ways in which they engage (or not) with decision making structures is likely to create feedback for wider union policies about the interests of these new groups. Evidence of activism and engagement with wider union structures may include evidence of workplace representation, campaigning and negotiation, establishment of structures which are able to represent worker interests relatively independently from officers, and evidence of members from target workplaces attending and engaging with decision making structures such as branch meetings, regional events, and annual conferences.

\section{2) Effectiveness of influence on managerial decision making}

Debates about how unions influence managerial decision making have already been highlighted. Certainly membership density is not related in any simple way to effective influence over managers. Indeed, UK employment relations are fully of examples of workplaces and sectors where efficient collective bargaining takes place in the absence of high levels of membership density or activism. Evidence of formal collective bargaining is clearly relevant as an organising outcome but we also need to look for evidence of the union's ability to influence managerial decision making more broadly. We therefore need to take account of the remit of the bargaining agenda, as well as any evidence that day-to-day managerial decision making is being influenced by the union. So, for example, it is possible to argue that a union that influences day-to-day managerial decision making in an informal manner through a network of active representatives at workplace level may, in some circumstances, be judged to be more effective than a union that agrees a loose framework of terms and conditions through collective bargaining, but which has little power to ensure the enforcement of that agreement. Similarly, evidence that managers routinely involve and consult the union in decisions as the consequence of an organising campaign would indicate a significant influence over managers.

Taken together, the central point here is that recognition for collective bargaining and conclusion of a bargained agreement are not sufficient measures for evaluating organising campaign outcomes. A 
broader perspective on the enforcement mechanisms for collective agreements and other evidence of unions influencing managerial decision making is also needed.

\section{3) Sustainability of organising outcomes}

What is often ignored in debates about organising is a third crucially important evaluative measure; the sustainability of organising outcomes. Specifically, the extent to which organising outcomes are durable after the resources of the initial organising campaign are withdrawn. Organising campaigns strive not simply to make an immediate change to working conditions, but to leave behind union structures that can continue to influence managers after the 'organising phase' of a campaign has ended (Simms, 2006). In the context of the UK, this typically involves both formal collective bargaining, and a system of representatives to engage with managers about the views of workers. There is increasing evidence from case studies that one of the most difficult aspects of organising activity is ensuring a successful transition from organising to representation (Markowitz, 2000; Simms, 2006; Wills, 2003). If union representation structures and effectiveness collapse after initial bargaining rounds, the long-term sustainability and effectiveness of the union's presence and influence in the workplace is surely called into question. Further, the sustainability of union structures also highlights the extent to which the workplace members and activists are (or are not) involved in the wider decision making structures of their union. Links and networks both horizontally (e.g. with other branches) and vertically (e.g. up to regional/national levels of the union) within and beyond the union take time to establish and are important evidence of the sustainability of outcomes. Thus, evidence of sustainability or collapse becomes the third and most important measure of organising outcomes.

Sustainability is also linked to, but not the same as, ideas about union power or union capacity (Dufour and Hege, 2000). For Lévesque and Murray $(2000 ; 493)$ the power resources of importance to local unions are workplace mechanisms to build democracy and cohesion amongst workers, the capacity of the union to build links outside the workplace both horizontally and vertically with other workplaces, other unions, and community groups, and the strategic capacity of unions to set their own agendas rather than only responding to employer actions. These authors show that established unions are able to be most effective, representative and stable when they have all three power resources. What is not known is whether this is also the case when unions are establishing themselves for the first time. Here, the power of the union in the longer term will depend not only on their ability to establish sustainable organising outcomes, but also on their ability to mobilise the membership and influence over managers to both reinforce the legitimacy of their representative function and, where judged necessary, to exercise coercive power such as industrial action. These questions of union power are extremely important in broader debates about union renewal and the impact of organising campaigns on aggregate (Simms and Charlwood, 2010), although they go beyond the focus of this paper. Further, it is also clear that issues such as the legislative constraints on unions, the shift towards neo-liberalism in recent decades, changes in class identities and social positions of workers also constrain the long-term effectiveness and representativeness of unions. This paper focuses on organising campaign outcomes and what helps create sustainable outcomes. What unions are then able to do with the outcomes they achieve is a separate discussion. 
Taking these three detailed measures of organising outcomes, we can develop an understanding of the factors that influence and explain them that is more refined than previous studies. To do that, it is important to explain the first section of Figure 1 - factors that influence campaign tactics and messages.

\section{Influences on organising tactics and outcomes}

Previous studies stress the importance of the tactics and messages adopted by the union during an organising campaign as having important influence on outcomes (Markowitz, 2000). The evidence indicates that a wide range of campaign tactics is more likely to be associated with securing recognition and increasing membership (Bronfenbrenner and Hickey, 1998), especially when applied using principles derived from mobilisation theory (Badigannavar and Kelly, 2005). The messages developed during the campaign have a strong influence on how the union develops during the representation phase (Markowitz, 2000; Simms, 2006), but little attention has been paid to evaluating what influences a union to adopt particular campaign tactics and messages. Three observable factors can be identified as influencing tactics and messages and these appear in the first column of Figure One: union structures, union policies and the behaviour of employers. Before looking at these, however, it is important to account for the influence of the wider socio-economic context on campaigns.

\section{1) Socio-economic context}

Evidently, the wider context within which a campaign takes place exerts considerable influence over the actors, tactics and outcomes (Freeman and Pelletier, 1999; Gall, 2004; Gennard, 2002; Oxenbridge et al. 2003; Undy, 2002). Simms and Charlwood (2010) classify four groups of external influences that require attention when explaining the outcomes of union renewal efforts: ideological resources, the political and legal context, product market conditions, and labour market conditions. Previous authors have pointed to the ideology of employers (Simms and Charlwood, 2010), governments (Smith and Morton, 2006) and union officers (Kelly and Heery, 1994) as helping to explain why those actors behave in the way they do in relation to union organising.

The central point here is that the consequences of judgments about the wider context can be seen in the behaviours of the key actors (unions, employers and workers). So, for example, the fact that the training organisation discussed in the later empirical section of this paper is a quasi-public sector organisation means that their service and labour markets face far less exposure to competition than, for example, the retail company or the casinos. This not only influences employers' judgments about how to engage with the union during an organising campaign, but also influences the decisions made by unions about which employers to target, when to invest resources in organising, and what tactics to use. It may also impact the decisions of individual employees about whether or not to join the union and engage in collective actions. Importantly, though, the influences of the wider context are 
complex and do not allow a simple 'read through' to predict the impact on actors' behaviours. So, despite the fact that the retail organisation operated in a much more competitive labour and product market than some of the other case study organisations, the employer was considerably more supportive to the union. The reasons for this are discussed later and can largely be understood to be the consequence of a tradition of paternalistic management combined with a desire to reduce the chance of being targeted by a more 'militant' union.

As a consequence, we can take the campaign as the unit of analysis and acknowledge these contextual factors by accepting that the decisions and behaviours of the key actors are an outcome of complex judgments influenced - but not determined - by the wider environment. Thus, the actions that are known and 'visible' (i.e. the behaviours of key actors during the campaign) are the focus of analysis here. The influence of these factors on campaign tactics and messages are filtered through the policies and structures of the unions undertaking the campaigns and the responses of employers to those tactics. Thus, the framework presented in Figure 1 captures proxy measures for those wider influences on the decisions of key actors.

\section{2) Union structures}

Internal structures are important to campaign tactics and outcomes because they influence the extent to which the union is open to new membership groups (Briskin, 1999; Dølvik and Waddington, 2002; McBride, 2001; Pernicka, 2005) and ways in which members are expected to engage in decision making within the union (Flynn et al., 2004). In turn, this influences the extent and nature of the involvement of newly organised members once bargaining has been established. Similarly, structures are likely to influence the overall organising strategy that informs the level at which the union is attempting to organise. Much UK organising activity focuses at workplace level, but some unions have attempted to develop a sectoral strategy that builds influence across and between workplaces (Simms and Holgate, 2010b). It is evident that a union with a sectoral strategy will still need to secure union support at workplace level, but the campaign tactics and messages given to workers during the campaign are likely to be different from those focusing only at workplace level.

\section{3) Union policies}

Union policies are important because they directly influence campaign tactics, and also what happens to new members once bargaining has been established. An example here might be whether a union has an organising policy that places greater emphasis on the role of membership activism or central co-ordination by union officers. The options open to newly organised members in unions adopting contrasting policies will vary so that, for example, one might expect members to be more engaged with identifying workplace issues in a union that encourages membership participation than their counterparts in a union that exerts greater central co-ordination (Markowitz, 2000). As we shall see, this distinction is important in influencing the sustainability of organising campaign outcomes with the most sustainable campaigns doing both. Unions also have very different policies 
as to how they engage employers once they have established a relationship with them. Some, including the retail union Usdaw, focus more on building consensual relationships (Heery 2002). Others, for example the transport union the RMT, have policies and traditions of more militant engagement with employers (Darlington 2009). This is relevant because it impacts not only the campaign tactics and messages, but how unions seek to secure effective influence over managerial decision making in the longer term. Union policy and structures are intertwined and reflect the particular history and membership. So the unions with a structure that prioritises representation of workers across sectors may have policies which encourage organising strategies to focus beyond the workplace, which in turn will influence campaign tactics, messages and the outcomes of those campaigns.

\section{4) Employer behaviour}

Employer responses to organising activity are clearly important in influencing the campaign tactics and messages as well as the eventual outcomes (Bain, 1970, Heery and Simms, 2004, Machin, 2000). An example relates to the extent to which the employer is supportive or hostile to organising efforts. Different responses will influence not only the campaign tactics used, but also the options available to the workers if/when they eventually secure union representation (Gall, 2004). Lévesque and Murray (2005), however, point out that unions are more likely to be able to influence managerial decision making where they are not simply responsive to managerial agendas, but when they set their own strategies. Thus, the dynamic interaction between union behaviour and employer behaviour becomes important to consider in the framework and further emphasises that it is not intended to be a static representation. Rather, the objective is to underline that these factors interact in a dynamic process of organising activity.

Overall, the framework presented in Figure 1 has two advantages over previous contributions. The first is that it attempts to capture judgments about a wider range of organising campaign outcomes whilst still being parsimonious. The second is that it looks not just to organising campaign tactics as explanatory factors facilitating or hindering particular outcomes but seeks to account for the influence of the wider context, union structures, union policies and employer behaviour. This, as we shall see, allows for a more robust explanation of the influences on campaign outcomes and especially on their sustainability (or otherwise).

\section{The research}

Evidence for this paper is taken from a 12 year longitudinal study (1998 to 2010) of the development of organising initiatives in UK trade unions. Detailed case studies were undertaken of five greenfield organising campaigns running between 1998 and 2005. They were selected because they were successful in establishing union structures in the workplace for the first time. The cases were identified in discussion with organisers and senior policy makers within the unions as examples of potentially 'successful' campaigns. Originally approximately 15 campaigns were identified, but most 
failed to achieve representation rights. These were the remaining ones that did achieve some formal representation rights to influence management decision making.

All five cases involved periods of non-participant observation of planning meetings, organising meetings with activists and the workforce, involvement in actions such as leafleting, and workshadowing the lead organisers while they planned and developed the campaigns. Periods of observation lasted from the identification of the campaign as a target, through to around a year after the campaigns had secured bargaining rights. Alongside the observation data, over the seven years of involvement in these campaigns, 102 participants were interviewed and 32 of them were interviewed more than once during that period - some as many as 4 times. Key participants included senior decision makers within the union, paid union organizers, generalist officers and negotiators, workplace activists, and workers including both members and non-members. Additional material on union strategies, policies and practices is drawn from over 200 further interviews with key actors at all levels of the UK union movement (members, activists, officials, organisers, policy makers etc.) and over 100 hours of observation, mainly of organiser training programmes such as the TUC's Organising Academy (Heery et al., 2000a). Finally, documentary materials were collected and analysed. Of particular relevance to the research presented here were copies of organising materials (leaflets, etc.), copies of collective bargaining agreements, and strategy documents from both the national union and the campaign. All text-based materials (interview transcripts, documents, observation notes) were entered into Nvivo and coded thematically. Themes were identified both from existing literature and new themes were added when it was clear that participants were raising issues that had not previously been discussed in detail in academic papers. Particularly relevant themes for this paper relate to descriptions of union decision making processes, structures of the union, relationships between officers and activists, descriptions of organising activities and outcomes, assessment and evaluation of outcomes, and any evidence of long-term 'problems' emerging from these 'successful' campaigns.

Table One summarises the key features of the five campaigns, including reference to each of the factors identified in the previous section. Inevitably, an academic paper cannot capture every detail of longitudinal research but the tables provide systematic evidence on the developments across the research period which are intended to supplement and summarise the evidence presented in the following sections. Further case description and analysis can be found in Simms $(2006,2007,2011)$. The tables are structured to reflect the factors in Figure One.

\section{TABLE ONE HERE}

\section{Evidence of organising outcomes}

Table Two summarises the outcomes of the campaigns as evaluated against the framework presented previously. Each of the variables identified previously appear in the table. 


\section{TABLE TWO HERE}

Evidence from the case studies illustrates the argument that both workplace engagement and central co-ordination are needed to build sustainable organising outcomes. The following section introduces the empirical evidence to highlight the complexity of the interactions between different features of campaigns and to stress the importance of understanding the ways in which those interactions influence campaign outcomes. This section first explains two of the campaigns (training organisation and retail chain) that were run with comparatively little member engagement, before describing the two campaigns (charity and call centre) that were run largely as an opportunistic response to worker demands for unionisation. This section concludes with a consideration of the campaign (casinos) that achieved a balance between the two.

Two cases (the training organisation and retail chain) were run primarily because the organisations were a strategic target for the unions involved. Specifically, the unions (PCS and Usdaw respectively) had a strong sectoral presence and some bargaining leverage both within the target workplaces and with other employers within the sectors. Importantly this was the case even prior to the launch of greenfield campaign. Although the unions targeted these employers for different reasons, both campaigns formed part of a wider strategy for strengthening the union's presence in the respective sectors. Further, the approach and outcome showed some similarities; the unions invested heavily in recruitment activity with relatively little time spent developing sustainable workplace activism prior to recognition. In this regard, the dominance of officers in the tactical decision making processes of organising campaigns is evident.

In these cases, the unions secured constructive and supportive relationships with the employers and used this as a basis of gaining access to the workplace to recruit members. In the case of the training organisation, this was largely explained by the fact that many workers and managers had previously been part of the public sector and were familiar with the 'culture' of trade unionism commonly found there. For the retail chain it was largely explained by a desire to professionalise the human resources function and to head off any demands for recognition from a more militant union. As a consequence of the relatively good relations with managers, access to the workplaces was comparatively easy and union recruitment was highly dependent on trained officials and organisers who focused largely on 'selling' the advantages of joining the union. Organising activity was focused on identifying activists and building branch structures in workplaces with the intention that these activists would increasingly take over recruitment and representation activity. However, in both unions, there is a strong emphasis on officers taking responsibility for negotiations and there was a clear intention that this would continue after representation and bargaining rights had been formally secured. Workplace activists were largely expected to be union recruiters and to act as a conduit for workplace grievances to be passed up to officers. In some cases, officers were effective at negotiating improvements to workplace grievances, but the kind of rank-and-file intensive 
organising campaign tactics advocated in much organising literature and training (Bronfenbrenner 1997; Bronfenbrenner and Juravich 1998) was certainly absent. The argument here relates to the anticipated role of activists. In these campaigns (unlike the ones described later) the expectation was that they did little more than recruiting colleagues, distributing union information, and referring problems up to officers. As a consequence, concessions were mainly granted because management responded to professional intervention from officers rather than the building up of collective pressure of members and activists. For this reason, Table 2 refers to these structures as weak with officers taking on most of the representative function.

In the training organisation, membership initially grew to around $40 \%$ density as a result of a concerted recruitment effort. Reflecting the statutory recognition legislation, management had agreed to concede a voluntary recognition deal if the union could demonstrate majority or near majority support. This prompted a significant effort on the part of the union to recruit quickly. Although the wider union structures within PCS union rely heavily on activists to build collective interests at workplace level, this campaign was unusual because it was identified as a strategic target rather than as an organisation where there was clear demand for membership. As a result, this campaign lacked effective and widespread activist engagement at workplace level. Unsurprisingly, membership quickly ebbed away so that a year after recognition it stood at less than $30 \%$ density. Activists and officers consistently noted the 'vicious circle' at both national and workplace levels of a reduced membership density leading to reduced bargaining influence, leading to less effective bargaining outcomes, leading to difficulties persuading workers to join the union. Assessed against the evaluation criteria, this campaign was initially successful at establishing representative union structures, and had some success in influencing managerial decision making over core terms and conditions of employment. But the membership was unsustainable and the relatively low union density seriously undermined the long-term effectiveness of officers by constraining their ability to place any coercive pressure on managers to concede negotiating wins.

The retail campaign outcomes were far more positive. The union (Usdaw) has a strategy of relying heavily on union officials and organisers to recruit members not just in newly organised workplaces. This reflects the fact that many retail stores are very small and the sector has a high labour turnover. The union calculates that it needs to recruit around one third of its membership each year just to remain in a steady state. Here, however, there was more evidence than in the training organisation of workplace representatives taking on some roles representing members in minor grievances. Density across all the workplaces was around $70 \%$ a year after recognition rights were granted and the union has established an effective bargaining relationship with the employer which fits with its wider strategy of seeking 'partnership' with employers where possible (Haynes and Allen, 2001, Heery, 2002). However, this is not a campaign that has established significant levels of membership activism, and it is important to note that it did not seek to. In many respects, then, this is an example of a highly effective organising campaign because of the reliance on paid union officers to recruit and represent members. Activists are involved in the wider union structures through attending meetings, engaging in policy making, and attending regional and sectoral forums and the outcomes appear largely sustainable in the longer term despite the fact that it differs significantly from the 
kind of member-led organising approach argued for by authors such as Fairbrother (1996) and Bramble (1995).

By contrast, one of the campaigns clearly highlights the potential difficulties of pursuing a membership-led approach to organising. The call centre campaign was run using this approach. In other words, it was initiated as a result of workers being aggrieved by managerial behaviour and contacting the union (a "hot-shop"). The campaign focused heavily on building workplace activism, collective responses to workplace grievances, and shared responsibility for development of campaign tactics, despite the fact that the sector was not the union's primary focus of membership or representation. The main weakness of this campaign was that these new members had little contact with the wider union (the CWU) which has its strongholds in the postal service and telecommunications employer, BT. Although they shared many features of their work with BT workers - especially call centre employees at BT - the union structures were so focused on representing the vast majority (well over $95 \%$ ) of members working for the two core employers that there were few structures for integrating new members from other employers. As a consequence these new members were extremely isolated once recognition had been gained. Notably, for example, most of the business of local, regional and national union committees dealt with issues arising in the two main employers.

Of course, the effort to target this call centre is evidence of the union's commitment to trying to organise more widely within the telecommunications sector. However, after recognition this campaign saw the withering away of the lively activism and strong membership engagement that had developed in the organising stages and a related decline in membership density. The relative isolation of this group of members and activists meant that although workplace union structures became established and bargaining rights were conceded (although crucially not over pay), there was some evidence that influence over managerial decision making, activism and membership declined over time. By a year after recognition rights were granted there was comparatively little evidence of the previously enthusiastic membership engagement. This was accounted for by the fact that their issues were largely unrelated to those within the broader union and their opportunities to engage effectively in the wider decision making structures were constrained. As a consequence, the workplace union was expected to sustain itself and negotiating officers often had little experience outside BT and the postal service. Together these constraints fundamentally challenged the longterm sustainability of the campaign outcomes.

The campaign at the charity was notable for two very different phases. At first, organising efforts began with a strong workplace focus similar to the call centre. The reactions of management prompted a change of strategy on the part of the union. Managers reacted very negatively to the initial member-led and issue-based campaigning phase and made it clear to the organisers and officials involved that they were prepared to open a channel of communication with the union on the condition that this approach was changed. Activists and officers accepted this as a means to ensuring that union structures were formally established within the workplace, and that they were 
effective in the sense that managers were prepared to engage with them. In the subsequent 'partnership' phase of the campaign, officers did make an effort to link these activists into the wider union structures, but these were essentially efforts to encourage activists to share information rather than to encourage them to engage fully in the democratic structures or to establish a workable sectoral strategy. The campaign resulted in very low membership density and, as a consequence, managers refused to concede full bargaining rights. The union does have an influence on managerial decision making both through formal seats on the consultative works council and in some workplaces where density is high. And there is evidence of managers collectively consulting staff and union activists on a range of personnel issues. It is also important to note that although the union has a presence in this sector, there was comparatively little effort to link activists in these workplaces to the wider union and activists reported that they felt that the wider affairs of the union were largely irrelevant to them. As a consequence, the campaign outcomes became highly unsustainable. This was exacerbated by the difficulties recruiting and engaging members in a very large number of small and geographically dispersed workplaces. As a consequence of the low membership density in both the sector and the workplaces, there was little opportunity to use any form of coercive influence over management to extend formal bargaining rights which created a vicious circle of ineffectiveness in representation similar to that discussed above.

Finally, the campaign in the casinos in London was run jointly by the TGWU (now Unite) and GMB unions and was notable for a very different approach from the others. The two unions developed an explicit strategy to try to gain bargaining leverage across the sector, albeit in one geographical location; London. The two unions established an agreement to co-operate in their recruitment and organising activity and were successful in targeting the five largest casino employers in London for recognition over a period of approximately 3 years. Activists built strong workplace campaigns around issues of concern to workers such as shift patterns and abusive customers. At the same time, regional officers and organisers co-ordinated actions, targeted resources and ensured that activists met regularly to discuss common issues and to plan tactics. The approach was extremely successful and after about three years of campaigning, recognition agreements had been concluded in all of the target employers. Managers granted some of the bargaining agreements voluntarily while others, including the one studied in depth for this research, were granted as a result of the statutory recognition legislation. What is important here is that both unions saw the workplace-level campaigns as part of a wider strategy and had clear plans to integrate the new members into the wider union. Activists and officers developed networks to share information and experience between workplaces and employers and officers have used the recognition agreements in the larger employers to put pressure on smaller employers to sign voluntary agreements. It is notable that along with the retail campaign, these are the two campaigns where membership in target workplaces has grown since recognition - although using very different approaches.

In this case, membership activism has been sustained by investing considerable time and effort in building representation structures linking the workplaces to the wider unions. This allowed branches to develop to co-ordinate sectoral representation across the London region and they have a clear constitutional place within the wider union structures. The development of the branch structure is 
part of a deliberate effort on the part of both activists and officers to develop a sectoral bargaining strategy which seeks to use concessions granted in bargaining with one employer to argue for similar improvements with other employers. Although, inevitably, this is not always successful, it is evidence of a very different kind of organising strategy than seen in the other campaigns. Importantly, this campaign shows evidence of success on the broadest measures of organising effectiveness. Membership and activism have proved to be sustainable and growing, structures are wellestablished, and the union has a degree of influence over managerial decision making both through formal collective bargaining and day-to-day enforcement of rules and procedures. Importantly, there is also a clear link between these new sectoral structures and the existing decision making structures of the respective unions.

\section{Multi-level policies and structures for sustainable organising}

These case studies illustrate the ways in which the wider context, union structures, policies and employer behaviour affect campaign tactics which, in turn, influence organising outcomes. They also highlight why the sustainability of membership and activism is argued here to be the most important measure of organising campaign outcomes. Of course this is a dynamic process, but the framework allows us to see and account for a wider range of outcomes than in previous literature and to understand the decisions and structures that facilitate those outcomes. And it is important to remember that the unions proclaimed all these campaigns as examples of organising success. Although all have been successful in establishing union representation at workplace level, it is clear that there is a strong case to develop a more nuanced understanding of organising outcomes and to emphasise the importance of sustainability. This evidence shows that the most sustainable outcomes are in the casino case which has both worker support and co-ordination from officers.

Taken against the wider measures of outcomes, the campaign in the training organisation is problematic because, although some progress has been made on national issues, there is little evidence of the union effectively dealing with workplace issues. Further, membership and representation structures are weak. In large part, this can be accounted for by the fact that this campaign was identified as a strategic target with little attention to the particular challenges of organising in these workplaces. In other words, the union policies drove a strategy for which there was not much support at workplace level. It was therefore extremely challenging to engage new members and encourage them to build the necessary skills to represent themselves effectively and to engage in the wider union structures. By contrast, the call centre campaign illustrates that focusing on workplace issues can be problematic as it can leave members isolated from the rest of the union. Again, workplace membership and representation structures have not proved durable. This can largely be explained because the union responded to the pressing demand and enthusiasm for unionisation emerging from the workplace, with little thought to the wider strategy or policy for integrating new members in areas beyond the core employers. The structures of the union mean that new members had to be located within branches that had little knowledge of working conditions outside BT. Branches are the primary mechanism for engaging in the wider structures of the union, so isolation within the branch means that members have few opportunities to participate. This also has consequences for the extent to which members can build up the necessary skills to 
operate effectively in bargaining and representation. Thus, we can see that the structure and policies of the union have affected the campaign tactics and outcomes.

The charity campaign failed to engage sufficient numbers of workers across the bargaining unit as a whole to secure strong and effective bargaining rights which limits the effectiveness of the workplace union and is related to the collapse of many of the workplace representation structures. It was identified as a strategic target and did have some support. But the response of the employer made it very difficult to secure sustainable, effective bargaining and representation. In order to overcome employer resistance, the union would have had to engage in very different organising campaign tactics to build more confrontational membership activism, which they had agreed with the employer not to do. This policy decision constrained the sustainability of the union in the longer term because it has limited the scope for bargaining and therefore the union's ability to deliver improvements in working conditions for its members.

Two of the campaigns (the retail chain and the casinos) can be judged to have generated more sustainable outcomes, despite significant differences between them. In both cases, we see workplace representation, growing membership, involvement in the wider union decision making, and some degree of the effective establishment of an on-going bargaining relationship with management. The central difference between the two campaigns is that, in keeping with the wider organising strategy, Usdaw's retail campaign is led by officers of the union. The casino campaign, although instigated and co-ordinated by officers, involves workplace activists to a far greater extent and it is notable that this is also in keeping with the organising policies and structures of the GMB and TGWU (now Unite).

In both campaigns, the unions have an explicit strategy that emphasises the importance of organising beyond individual workplaces, although this is driven by very different policies in the two unions. Usdaw has developed a structure and policies that place the responsibility for building sustainable outcomes on paid organisers and officers. This is largely a result of factors within the external context such as the high labour turnover in retail, which has knock on consequences for a high membership turnover for Usdaw. Together with the largely moderate policy of 'partnership' adopted by the union, this helps to explain why organising activities are driven from officers (Heery, 2002). These policies fundamentally inform organising tactics which, in turn, influence organising outcomes. Some authors (Danford et al., 2005) have been critical of this approach and there are potential weaknesses. Officers' time is expensive, and membership activism and engagement with the wider union is lower than in the casino campaign because workplace representatives generally take few responsibilities beyond distributing information and basic recruitment. More importantly, this case highlights that the union is also highly dependent on a relatively compliant employer who actively encourages union membership and supports the union in achieving its organising objectives. 
In the casino campaign, by contrast, the policy to focus organising at a sectoral (if geographically constrained) level had been developed as a response to the realisation that bargaining leverage would be weakened if the unions focused on organising 'islands' of unionism in a sectoral 'sea' of non-unionism. This sectoral strategy has allowed activists in the unions to engage both with each other and the wider unions, thus securing resources and support for the campaign and ensuring sustainability, effectiveness and representativeness in the post-recognition phase. This member engagement with the wider union was largely absent from the other campaigns (as shown in Table 2) yet has proved to be extremely important as it ensured that these activists were not isolated from the wider union. The CWU call centre campaign, by contrast, perhaps most clearly shows the weakness of focusing on the workplace without broader engagement in the union. The activists within the call centre had little understanding of or engagement with the work of the wider union, and no meaningful engagement in the decision making structures of the union beyond the workplace. This isolation both limited the bargaining leverage of the union because negotiating officers had little understanding of their work and employer, and worked to exclude activists from branch meetings and other structures, thus giving few opportunities for these members to make the case for greater resourcing. The structures and policies of the two unions in the casino campaign encouraged them to develop strong workplace activism and to integrate new members into the union through sectoral and regional branches. Combined with the sectoral strategy, bargaining and representation have been comparatively effective in influencing managerial decision making, thus creating conditions conducive for sustainable organising outcomes.

Leaders are important in these campaigns because they facilitate this 'articulation' of policy and practice between the workplace and central union. Importantly, leaders are both workplace activists and officers (Simms 2011). The cases allow us to understand how and why the articulation mechanisms are important in facilitating sustainable outcomes. The evidence illustrates how the engagement of both workplace activists and officers helps establish and reinforce the representativeness and effectiveness of the union by ensuring that both are working towards mutually understood objectives. Crucially, however, this is not a simple process of one group asserting dominance over the other, although there may well be differences of approach and perhaps effectiveness between officers who take different approaches to organising work. Kelly and Heery (1994: 25) identified differences of approach between "leaderist" officers who may be more prepared to let members develop their own agendas and campaigns, as compared to "managerialist" officers who placed more emphasis on ensuring that the rules and structures of the union were adhered to even where this may stifle activism. It is easy to imagine that these approaches to union work and engagement with members may lead officers to develop different approaches to organising work, but this would require further research to evaluate systematically. What this data shows is that where there is strategic oversight of organising, and where objectives are mutually agreed and understood between officers and activists, organising outcomes are more sustainable than in campaigns where these features are not present.

Taken in the round, these findings emphasise the importance of unions bringing together both the representativeness outcomes and the effectiveness outcomes highlighted in the framework (Figure 
1). Unions can establish workplace representation when only one is present. But the most sustainable outcomes appear to be when unions are able to integrate aspects of both. It is also evident that if organising is to repay the risky investment from unions, then sustainability of outcomes is essential.

\section{Conclusion}

Returning to the debates outlined in the outset, it is clear that it is essential to evaluate organising activity on a broader range of measures than in many previous studies. Hickey et al. (2010) rightly problematise the view that membership activism is the most important factor in explaining union organising outcomes. This evidence supports that analysis and extends it by presenting a framework through which to analyse a more nuanced range of organising outcomes and the factors that facilitate or hinder sustainable outcomes. The central contribution of the framework in Figure One is to argue that the most important evaluation of organising campaigns is the extent to which structures for effective representation and influence over managerial decision making are sustainable over time.

An important conclusion emerging from the cases is that a favourable socio-economic context for a campaign is neither sufficient nor necessary to secure sustainable organising outcomes. This is particularly evident when we look at the influence of the labour market and product market on outcomes. We might predict that a stable business context might allow for more effective, representative and sustainable outcomes than a highly competitive product/service market. However, the outcomes in the highly competitive casino sector appear more sustainable than, for example, the monopoly supplier (call centre) or the quasi-public sector organisation (the training organisation). This strongly reinforces the point made by previous research (Bronfenbrenner and Juravich 1998) that union behaviour 'matters' in organising campaign outcomes. Unions can, sometimes, build successful organising campaigns in unfavourable circumstances if they pay attention to ensuring that their structures and policies support both member activism and leadership from officers. Exactly how those two come together is influenced by the history, structure and policies of the union, the behaviour of the employer being targeted, and the context within which the campaign takes place. But this evidence strongly indicates that even where the product market and/or labour market are extremely competitive, unions can deliver sustainable organising outcomes.

Few studies have systematically assessed the interactions of these influences in different campaign contexts. These cases show that union structures such as the openness to new membership and the extent to which campaigns are organised at workplace, sectoral or national levels influence campaign tactics such as the extent to which newly organising groups connect to other membership groups beyond the workplace. In turn, this influences the sustainability of campaign outcomes because it affects, for example, the ways in which new membership groups engage in the decision making structures of the union. Union policies such as the approach to employers, policies relating 
to the expected roles of new members and activists, and policies about the expected roles of paid officers and organisers influence campaign tactics such as the extent to which workplace activists are required to take on responsibility for identifying collective grievances and representing workers during a campaign. In turn, this influences the sustainability of campaign outcomes because it affects, for example, the skills of newly organised workplace representatives and their expectations of how to "be union" (Markowitz, 2000). Employer behaviour influences campaign tactics and outcomes by defining the terrain on which the campaign is undertaken (Heery and Simms, 2010) but not always in simple ways. Employer support can help build sustainable outcomes by providing resources and legitimacy for continued union involvement in managerial decision making. Resistance from employers can challenge the sustainability of outcomes, but can also facilitate innovation in campaign tactics and union policies that help create stronger and more sustainable outcomes, as in the casino campaign.

The evidence reaffirms support for the argument of researchers such as Voss and Sherman (2000) and Markowitz (2000) that there are important roles for both workplace activists and union officers in building sustainable organising outcomes. Workplace activists are often not well placed to develop organising policies reaching beyond their workplace, and in most UK unions, that role can most feasibly be taken on by officers. This counters the view of authors such as Fairbrother (1996) and Bramble (1995) that workplace organising and the role of workplace activists in union renewal efforts should be prioritised over that of officers. While it is quite possible that officers can sometimes act as a brake on the ideas and wishes of workplace activists, this research indicates an important role for them in developing policies and structures that extend beyond the workplace. In this regard, the role of officers in providing co-ordinated leadership in organising campaigns seems particularly relevant. The particular contribution of this research is to explain why this multi-level approach matters so much: it appears to be central in ensuring the sustainability of organising outcomes.

This multi-level approach seems important to overcome the potential weaknesses of many approaches to organising within UK unions. It also helps explain why over a decade of organising investment and activity within the UK has yielded little evidence of aggregate union renewal. A great deal of current greenfield organising policy is focused on gaining recognition in individual workplaces, with little coherent analysis of how to build sustainable representation and influence. Membership tends to ebb away if unions are unable to show their effectiveness (Terry, 2003), and an understanding of sustainable outcomes that concentrates only on the workplace level is a limited one. It is also important to note that although the framework is developed in the context of UK greenfield organising campaigns, it has the potential to be more widely applicable and further research may be able to establish its generalisability beyond this context.

Sustainable organising is essential to any hope of wider union renewal because it relates directly to issues of union power. In workplaces with established unions, Lévesque and Murray (2005) found that unions with strong internal and external power resources which also pursued their own 
agendas rather than simply being reactive were more effective in influencing managerial decision making. This data shows that a similar conclusion can be reached where unions are establishing themselves for the first time, indicating that the Lévesque and Murray (2005) conclusion is more widely applicable. These three factors taken together allow the key actors within unions to craft campaigns that are appropriate for individual workplaces building on the internal and external power resources available to develop effective, representative and sustainable influence over management.

A wider question remains as to how these findings influence the implicit 'cost-benefit' evaluation made by unions in decisions about which campaigns to support and how to organise. The sectoral structures of the casino campaign clearly delivered significant advantages to the company-level campaigns and they would not be particularly difficult or expensive to replicate in other unions and other sectors. But even if sectoral strategies were problematic, the broader conclusion is that the central advantage of these structures was the co-ordination effect. By providing a structure within which campaigns within individual workplaces could be co-ordinated, the union was able to provide leadership from experienced officers whilst still giving a good deal of autonomy to workplace activists. Developing mechanisms to effectively "articulate" policy, practice and interests in this way is not costly and can be replicated if unions are attentive to the issues and have the will to ensure these systems are working well.

It is important, however, to end on a note of caution. The focus of this paper has been on explaining the dynamics of union organising campaigns and argued that the broader political, economic and legislative contexts can be evaluated through the behaviours of the key actors during campaign activity. Nonetheless, the wider context must not be ignored when discussing the challenges to union organising activity on aggregate. It is clear that unions are "intermediary organisations" (Mueller-Jentsch, 1985) and therefore have to respond to the changing social, political and economic contexts. Union strategies need to account for and be responsive to the circumstances within which they find themselves (Hyman, 2007), and it is clear that many wider challenges remain which may limit the aggregate success of organising activity even where individual campaigns prove sustainable. 


\section{Bibliography}

Badigannavar, V. and Kelly, J. (2005). Why are some union organizing campaigns more successful than others? British Journal of Industrial Relations, 43(3): 515-535.

Bain, G. S. (1970). The Growth of White-Collar Unionism. Oxford: Oxford University Press.

Bramble, T. (1995). Deterring democracy? Australia's new generation of trade union officials. The Journal of Industrial Relations, September 1995: 401-426.

Briskin, L. (1999). Autonomy, diversity and integration: union women's separate organizing in North America and Western Europe in the context of restructuring and globalization. Women's Studies International Forum, 22: 543-54.

Bronfenbrenner, K. (1997). The role of union strategies in NLRB certification elections. Industrial and Labor Relations Review, 50(2): 195-212.

Bronfenbrenner, K. and Juravich, T. (1998). It takes more than housecalls: organizing to win with a comprehensive union-building strategy in Bronfenbrenner, K., Friedman, S., Hurd, RW., Oswald, RA., and Seeber, RL. (eds.) Organizing to Win: New Research on Union Strategies. Ithaca, New York: Cornell University Press.

Carter, B. (2000). Adoption of the organising model in British trade unions: some evidence from Manufacturing, Science and Finance. Work, Employment and Society, 14(1): 117-136.

Carter, B., Fairbrother, P., Sherman, R., and Voss, K. (2003). Made in the USA, imported into Britain: the organising model and the limits of transferability in D. Confield and $\mathrm{H}$. McCammon (eds.) Labor Revitalization: Global Perspectives and New Initiatives. Oxford: Elsevier.

Charlwood, A. (2004). Influences on trade union organising effectiveness in Britain. British Journal of Industrial Relations, 42(1): 69-93.

Crosby, J. (2005). Democracy, density and transformation: we need them all. WorkingUSA, 8 (December): 733-753.

Danford, A., Richardson, M., Stewart, P., Tailby, S., and Upchurch, M. (2005). Workplace partnership and employee voice in the UK: comparative case studies of union strategy and worker experience. Economic and Industrial Democracy, 26(4): 593-620.

Darlington, R. (2009). Leadership and union militancy: the case of the RMT. Capital and Class. 33(3): 3-32.

Dølvik, J. and Waddington, J. (2004). Organizing marketized services: are trade unions up to the job? Economic and Industrial Democracy, 25(1): 9-40.

Fairbrother, P. (1989). Workplace Unionism in the 1980s: A Process of Renewal. London: Workers Educational Association. 
Fairbrother, P. (1996). Workplace trade unionism in the state sector in P. Ackers, C. Smith and P. Smith (eds.) The New Workplace and Trade Unionism. London: Routledge.

Fairbrother, P. (2000). Unions at the Crossroads. London: Mansell.

Fairbrother, P. and Stewart, P. (2003). The dilemmas of social partnership and union organization: questions for British trade unions in P. Fairbrother and C. Yates (eds.) Trade Unions in Renewal: A Comparative Study. London: Continuum Press.

Fairborther, P. and Yates, C. (2003). Trade Unions in Renewal: A Comparative Study. London: Continuum Press.

Ferguson, J-P. (2008). The eyes of the needles: a sequential model of union organizing drives 19992004. Industrial and Labor Relations Review, 62(1): 3-22.

Fiorito, J., Jarley, P., and Delaney, J. (1995). National union effectiveness in organizing: measurements and influences. Industrial and Labor Relations Review, 48(4): 613-635.

Flynn, M., Smith, R., Rigby, M. and Brewster, C. (2004). Trade Union Democracy: Issues and Contestations in M. Harcourt and G. Wood (eds.) Trade Unions and Democracy: Strategies and Perspectives. Manchester: Manchester University Press.

Freeman, R. and Pelletier, J. (1990). The impact of industrial relations legislation on British union density. British Journal of Industrial Relations, 28(2): 141-164.

Gall, G. (2004). Trade union recognition in Britain 1995-2002: turning a corner? Industrial Relations Journal, 35(3): 249-270.

Gennard, J. (2002). Employee relations public policy developments, 1997-2001: a break from the past? Employee Relations, 24 No.(6): 581-94.

Haynes, P and Allen, M. (2001). 'Partnership as union strategy: a preliminary evaluation' Employee Relations, 23(3): 164-187.

Heery, E. (2002). Partnership versus organising: alternative futures for British trade unionism. Industrial Relations Journal, 33(1): 20-35.

Heery, E., Simms, M., Delbridge, R., Salmon, J., and Simpson, D. (2000a). The TUC's Organising Academy: an assessment. Industrial Relations Journal. 31(1): $400-415$.

Heery, E., Simms, M., Delbridge, R., Salmon, J., and Simpson, D. (2000b). Union organising in Britain: a survey of policy and practice. International Journal of Human Resource Management, 11(5): 9861007.

Heery, E., Delbridge, R., Simms, M., Salmon, J. and Simpson, D. (2003a). Organising for renewal: a case study of the UK'S Organising Academy in D. Confield and H. McCammon (eds.) Labor Revitalization: Global Perspectives and New Initiatives. Elsevier, Oxford.

Heery, E., Kelly, J., and Waddington, J. (2003b). Union revitalisation in Britain. European Journal of Industrial Relations, 9(1): 79-97. 
Heery, E. and Simms, M. (2010). Employer responses to union organizing. Human Resource Management Journal, 20(1): 3-22.

Hickey, R., Kuruvilla, S., and Lakhani, T. (2010). No panacea for success: member activism, organizing and union renewal. British Journal of Industrial Relations, 48(1): 53-83.

Kelly, J. and Heery, E. (1994). Working for the Union: British Trade Union Officers. Cambridge: Cambridge University Press.

Lévesque, C. and Murray, G. (2005). Union involvement in workplace change: a comparative study of local unions in Canada and Mexico. British Journal of Industrial Relations, 43(3): 489-514.

Lynn, M. and Brister, J. (1989). Trends in union organizing issues and tactics. Industrial Relations Journal, 28(1):104-113.

McBride, A. (2001). Gender Democracy in Trade Unions. Aldershot: Ashgate.

Machin, S. (2000). Union decline in Britain. British Journal of Industrial Relations, 38(4): 631-645.

Markowitz, L. (2000). Worker Activism After Successful Union Organizing. Armonk, New York: ME Sharpe.

Mueller-Jentsch, W. (1985). Trade unions as intermediary organizations. Economic and Industrial Democracy, 6(1): 3-33.

Oxenbridge, S., Brown, W., Deakin, S. and Pratten, C. (2003). Initial responses to the recognition provisions of the Employment Relations Act 1999, British Journal of Industrial Relations, 41(2): 31534.

Pernicka, S. (2005). The evolution of union politics for atypical employees: a comparison between German and Austrian trade unions in the private service sector. Economic and Industrial Democracy, 26(2): 205-228.

Simms, M. (2006). The transition from organizing to recognition: a case study in G. Gall (ed.)Union Recognition: Organising and Bargaining Outcomes. London: Routledge.

Simms, M. (2007). Managed activism: two union organising campaigns in the not-for-profit sector. Industrial Relations Journal, 38(2): 119-135.

Simms, M. (2011) 'Les militants de terrain dans les campagnes d'implantation syndicale dans le secteur de services en Grande-Bretagne' La Revue d'IRES. 68 (October): 75-108.

Simms, M. and Charlwood, A. (2010). Trade unions: power and influence in a changed context in T. Colling and M. Terry (eds.) Industrial Relations: Theory and Practice. London: Wiley.

Smith, P. and Morton, G. (2006). Nine years of New Labour: neoliberalism and workers' rights. British Journal of Industrial Relations, 44(3): 401-420.

Terry, M. (2003). Can 'partnership' reverse the decline of British trade unions? Work, Employment and Society, 17(3): 459-472. 
Undy, R. (2002). New Labour and New Unionism 1997-2001: But is it the Same Old Story? Employee Relations, 24(6): 638-655.

Voss, K., and Sherman, R. (2000). Breaking the iron law of oligarchy: union revitalization in the American labor movement. American Journal of Sociology, 106(2): 303-349.

Wills, J. (2003). Organizing in transport and travel: learning lessons from TSSA's Seacat campaign in G. Gall (ed.) Union Organizing: Campaigning for Trade Union Recognition. Routledge. London. 133 152. 